\title{
EXAMINING OF THE EFFECTS OF MANAGEMENT CAPABILITY AND TECHNOLOGY ORIENTATION ON PRODUCTION COMPANIES, PRODUCT INNOVATION AND BUSINESS PERFORMANCE
}

\author{
*Kudret CELTEKLIGIL (Orcid ID: 0000-0003-2924-292X) \\ **Zafer ADIGUZEL (Orcid ID: 0000-0001-8743-356X) \\ *Beykent University \\ **Istanbul Medipol University
}

\begin{abstract}
One of the most important features of the manufacturing companies lies in the technological infrastructure used. Investment in technology is important to ensure innovation in production. Both product innovation and widespread use of technology are directly proportional to the capability of management. Management capability has an important feature in ensuring employee participation in the organization and in fulfilling the performance criteria. The aim of the research is to investigate the effect of technology focus on product innovation and business performance in the production companies located in the organized industrial zones in Istanbul, and also the effect of management capability on technology and product innovation. The questionnaires were collected from engineers working in technology-oriented manufacturing companies located in the organized industrial zones in Istanbul. The data was obtained from the sample analysed with SPSS 25 program. Factor and reliability, mean of variables loaded on each factor, correlation and regression analyses were performed. Sobel test was also performed for mediation effect. By analysing the data obtained as a result of the research, we can see that management capability and technology orientation positively affect both product innovation and business performance. At the same time, when the mediation effect of technology orientation is examined, a meaningless result emerges in terms of its effect on product innovation, but it can be explained that there is a significant relationship in terms of its effect on business performance.
\end{abstract}

Keywords: Management Capability, Technology Orientation, Product Innovation, Innovation, Business Performance

\section{INTRODUCTION}

Technology has become the most important competitive element. In the global structure, nations, companies and multinational companies are examining the competition and it is seen that technology, technological development, technology management, technological talent, knowledge management, and innovation management activities take the first place in creating competitiveness. This study focuses on technology, product innovation, and management capability as the central processes in technology management, information management and innovation management play an important role in competitiveness. While focusing on the market in changing environmental conditions, focusing on technological developments is also critical for companies to gain competitive advantage and superior performance. Managers' understanding of performance is to show a constantly changing and renewed process from past to present. In this process, the understanding of performance that has lost its value, has been re-established and gained more importance has emerged. Generally; traditional methods represent old and outdated and contemporary methods represent new and modern performance evaluation practices (Neely, 2007). Management, which is basically influenced by the science of economics and is defined as designing, creating and sustaining the environment for individuals to work in groups in order to obtain the aims efficiently, started to develop after the industrial revolution as a theory (Weihrich and Koontz, 1993; Calás and Smircich, 2019). Nowadays, the characteristics of new product studies are from to innovation- 
based; from sequential linear model to dynamic model based on close interaction with technological developments and market changes; from single discipline to interdisciplinary studies; from product features to creating value for the customer (Fritsch and Meschede, 2001). In the 2000s, the rate of change in technology and market increased significantly. The innovative product development capabilities and capacities of the enterprises have become the focal point of success in an intense competitive environment (Baxter, 2018). For this reason, management capability has an important place in order to make technology orientation effective both in performance and innovation (Unsal and Cetindamar, 2015). However, the main reason why companies attach importance to product innovation; Intense and difficult competition in the market, numerous market segments, rapid technology change. In addition, customer needs change and equalize, the life of the products is gradually shortening, and the need for new products is constantly increasing to meet customer expectations and wishes. In other words, this type of innovation is directly related to customer expectations and demands and results from the changes made by the companies in the products they offer to the market (Johne, 2018). Successful management capability, the desired level of technology orientation, the contribution of business units or employees to the objectives of the business in which they are located can be demonstrated by directly determining the performance of the unit or employees (Grady, 1991). It is important to measure the performance of businesses in order to identify the sectors in which they operate, to find possible differences by comparing and to improve the quality of internal and external activities (Bilgen, 2001). The aim of this research is to investigate the relationship between management capability, technology orientation, product innovation and business performance.

\section{LITERATURE REVIEW Management Capability}

According to Selznick (2011), capabilities are the distinctive elements of the enterprise that have the potential to drive the firm forward. Capabilities are positioned as a source of strategic competition. Prahalad and Hamel (1990) stated that all kinds of knowledge, mastery, experience and cultural codes are transformed into technical processes in businesses, and they are expressed as a product of sharing-based learning capabilities, creating a non-repeatable competitive power by transforming into basic businessspecific skills. The management capability of the top management of organizations is considered as one of the important elements that can lead the organizations to success in their activities (Mithas et al. 2011). One of the main reasons for this is that senior executives, who have the capability to manage, create a sustainable organization by applying their skills on how organizations should be managed and controlled in terms of organization (Rothaermel and Deeds, 2006). In this way, organizations have a manageable structure. It is very important to adopt all efforts at the management level in order to create and manage an organizational structure based on capabilities (Yavuz and Zehir, 2014). On the other hand, management capability can be defined as the implementation of integrated strategies or systems designed to recruit, develop and retain people with the skills and attitudes necessary to meet existing and future organizational needs. It can be stated that a closer examination of this definition reveals an understanding that capability management has become synonymous with human resources functions such as workforce planning, recruitment, learning, development and retention as an expression and concept (Abraham, 2011). The research model examines the effects of management capability on technology orientation, product innovation and business performance.

\section{Technology Orientation}

The fact that technological superiority is the determining factor in today's consumers' product and service preferences has brought the concept of technology orientation to a central point in the long-term success of companies and has been seen as one of the most important strategic orientations (Zhou et al. 2005). While companies are trying to update and strengthen their technology bases to increase their competitive advantages due to the rapid spread of new technologies, they also face significant resistance to adopting the innovations brought by these new technologies within the company (Zhou and Li, 2007). Technology orientation enables a company in order to develop more innovative and superior products. Gatignon and Xuereb (1997) indicated that companies can proactively gain superiority in creating new product ideas, developing new technologies, integrating new technologies and using advanced technologies in new product development (Gatignon and Xuereb, 1997). In order to be successful in technology orientation, the experiences and capability of management and employees are important (Im et al. 2016). Especially the 
creative capability of management can have a positive effect on technology orientation. For this reason, technology-based advantages give the company a great competitive advantage that cannot be easily imitated by its rivals. These competitive advantages and internal processes developed through technology orientation will positively affect the overall performance of the company, leading to more satisfied customers, superior performance and higher operating income (Rajala and Westerlund, 2012). On the other hand, from resource dependence view, firms leaded by technology orientation collect rich technological knowledge through the collection of up-to-date technological information, which could be used to form a new technological solution in order to meet new market demand (Saqib et al. 2018). In the given theoretical context, the following hypotheses have been tested;

\section{H1: Management capability has a positive effect on technology orientation}

H6: There is a mediation variable positive effect of technology orientation on the relationship between management capability and product innovation

H7: There is a mediation variable positive effect of technology orientation on the relationship between management capability and business performance

\section{Product Innovation}

Product innovation is to launch a new product or to develop new outputs by developing new products (Johne, 2018). The meaning of the new concept here refers to being new for business, consumer, user, manufacturer, distributor and product technology and for their combination. Successful product innovation includes four elements. These include: (1) combining market needs and technological potential (2) incorporating creative solutions produced into problems (3) managing the process well and (4) deciding to engage in this issue (Dougherty, 2017; Dunne and Dougherty, 2016). Product innovation is a progression that increases the life expectancy and competition value of a new product or service or an existing product or service (Jajja et al. 2017). In this regard, Product innovation is one of the key business processes that transform the needs and opportunities around the enterprise into satisfied needs and occasions (Zehir et al. 2017). Product innovation is basically an important process for developing products and services or for renewing them to create completely new products and services, and for securing the future of the enterprise (De Massis et al. 2015). Product innovation is associated with a new product or service, or an existing product or it is an improvement that increases service life and competitive value (Estrada et al. 2016). Furthermore, risk taking is the intentness of an entrepreneurial firm to invest in or engage in an initiative or project that can be rather vague or unknown, such as engaging in courageous actions such as entering new markets. This means that the firm is afraid to move away from routine, riskless, reputable activities and want to enter the unknown. On the other hand, proactivity is defined as acting with the expectation of future problems, needs or changes (Wujiabudula and Zehir, 2016). It represents the company's vision in search of new opportunities, anticipating future demands and needs in the market, including the introduction of new products or services in front of rivals (Aloulou, 2019). In the given theoretical context, the following hypotheses have been tested;

\section{H2: Management capability has a positive effect on product innovation}

\section{H4: Technology orientation has a positive effect on product innovation}

\section{Business Performance}

While organizations continue their lives in today's conditions where change is inevitable, their capability to cope with their competitors and maintain this competition depends on their desired and required performance. Business performance is "the fulfilment and completion of a particular job (Chiu, 2005). Business performance means taking into consideration the quantity, quality, time and cost effectiveness of a job (Zehir and Hemedan, 2020). Employees' performance is determined by their personal characteristics and capabilities within the organization, the desire to succeed in their work, the capability of management to mobilize this desire and the working environment provided (Smith and Goddard, 2002). One of the most important reasons for looking at the performance of the institutions is that the stakeholders investing in the institution want to be informed about how much earnings they have as a result of the capital they invest. In order for organizations to achieve their goals and objectives, business owners determine the decisions they need to take about the steps to be taken by following the performance. The other important factor in the 
performance measurement is that those who want to invest make decisions by looking at the financial and productivity reports of the enterprises (Prajogo, 2016). The performance is important for the management and the performance data of the previous years is important for the future decisions. In terms of employees, the increase in the wages they receive for their labour and the premium system are directly proportional to how good the organization's performance is. Therefore, they follow the outputs of the employees regarding the performance of the organization. At the same time, in non-profit organizations, they pay attention to their performance in order to continue their activities. In 2003, Behn found eight important concepts for performance measurement: (1) assess; (2) power; (3) finances; (4); (5) promote; (6) praise; (7) memorize; and (8) development (Behn, 2003). Organizations give importance to performance criteria in order to be in a better position against competitors in the future. Stakeholders who want to have information about organizations are looking at financial reports. In addition to financial reports, they can also look at market performance to see if the business is sustainable in the long run (Lee et al. 2015). In the given theoretical context, the following hypotheses have been tested;

\section{H3: Management capability has a positive effect on business performance}

H5: Technology orientation has a positive effect on business performance

\section{Research Framework}

Based on the literature review, Independent Variable (IV); Management Capability, Mediation Variable (MV); Technology Orientation, Dependent Variables (DV); Product Innovation and Business Performance. In this study, the data were analysed to determine the relationship between statistical concepts due to a quantitative approach. Generally, we use the independent variable or independent variables to try the effect on the dependent variable in a quantitative research test (Thomas et al. 2015).

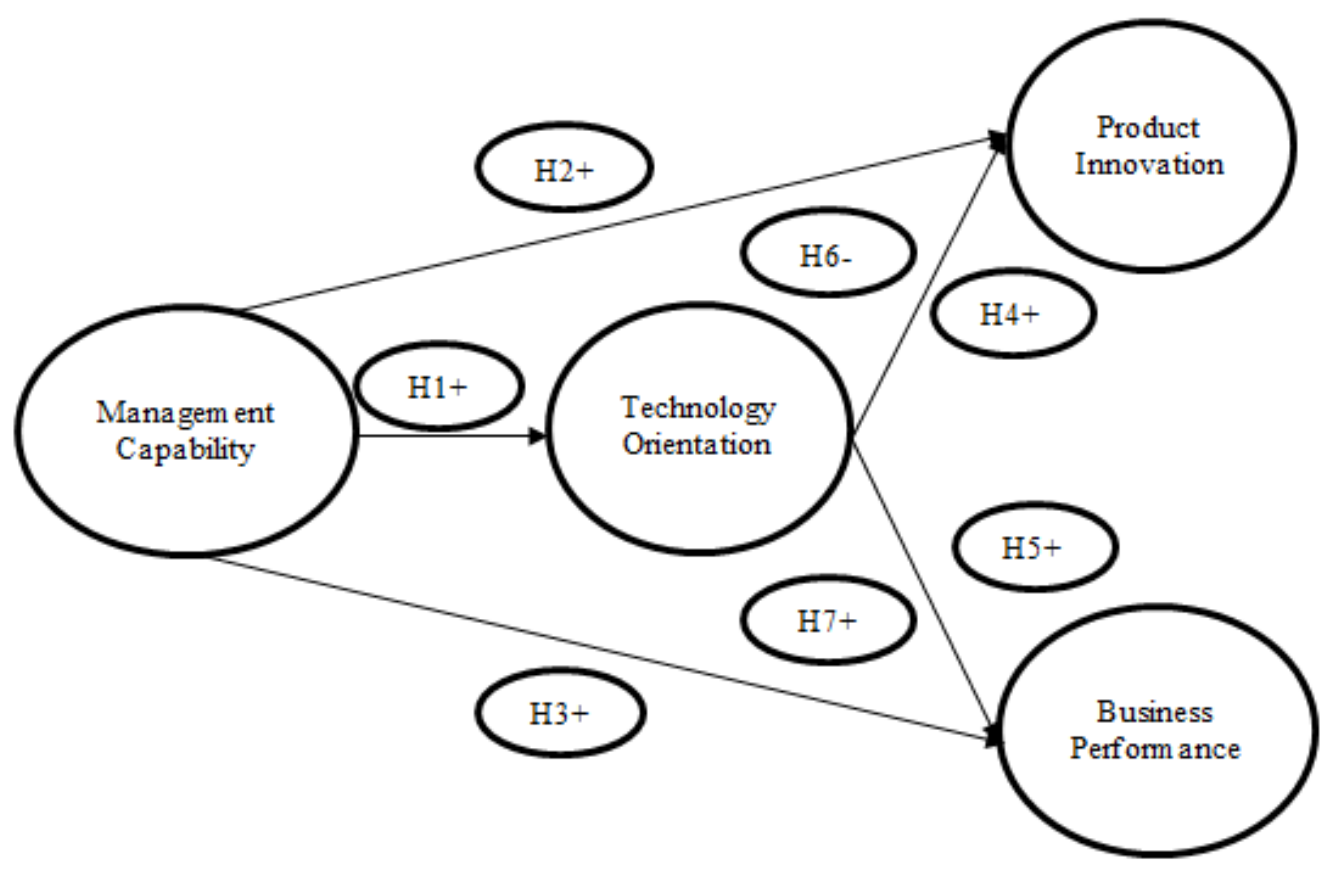

Figure 1. Research Model

\section{METHODOLOGY}

The aim of this research is to investigate the effect of technology orientation on product innovation and business performance in the technology-oriented manufacturing companies located in the organized industrial zones in Istanbul and to investigate the effect of management capability on technology and product innovation. The questionnaires were collected from engineers working in technology-oriented manufacturing companies. SPSS 25 program was used to analyse the data obtained from the sample 
population with the survey application. Factor and reliability, mean of variables loaded on each factor, correlation and regression analyses were performed. Sobel test was also performed for mediation effect. The questionnaire consists of four variables. In the first part of the questionnaire, demographic information and job-related information of the individuals are given. In the second part of the questionnaire, there are questions by representing 4 variables.

\section{Research Goal}

The main purpose of this research is to obtain data on the effects of management capability and technology orientation on business performance and product innovation, and to examine these data with scientific research methods to reach meaningful scientific results.

\section{Measurement Tools (Scales)}

The management capability scale was obtained from the scales in the studies conducted by Schilke and Goerzen (2010) and Simonin (1997). Technology orientation scale was obtained from the scale in the studies conducted by Atuahene-Gima and Ko (2001), Venkatraman (1989), Zhou et al. (2005). 5-point Likert scale was used, ranging from "strongly disagree" to "strongly agree". Product innovation scale was obtained from the scale in the studies conducted by Jajja et al. (2017), Fynes et al. (2015), Jean et al. (2014), Business performance scale was obtained from the scale in the studies conducted by Li et al. (2006), Martínez Sánchez and Pérez Pérez (2005), Yang et al. (2011), Kannan and Tan (2002).

\section{Sampling}

It has been applied to 310 white collar (engineers) employees working in different departments of companies. 310 people are sufficient for population size and 5\% significance level (Yazıcığlu and Erdogan, 2004). 202 (73\%) males and 108 (27\%) females have answered the questionnaire. 108 (37\%) of the participants were in the 17-27 age group; $159(49.7 \%)$ are in the 28-40 age group. The number of managers over the age of 31 was 53 (13.3\%). 230 (74\%) of the respondents were university graduates; 80 (26\%) have master's degree. The level of achievement of the goals determined by the employees individually; 24 participants stated that they achieved their targets as "Very Low", 47 participants stated that they were Low ", 107 participants stated that they were "Medium", 96 participants stated that they were "High", 36 participants stated that they were "Very High".

\section{Analyses}

KMO test and Bartlett sphericity test were applied to determine the suitability of the data set for factor analysis. If the KMO value is .921 and the Bartlett test is $\alpha=0.00$, the sample size is considered appropriate and sufficient for factor analysis. 
Table 1. Rotated Component Matrix ${ }^{\mathrm{a}}$

\begin{tabular}{|c|c|c|c|c|}
\hline \multicolumn{5}{|l|}{ Rotated Component Matrix ${ }^{a}$} \\
\hline & \multicolumn{4}{|c|}{ Component } \\
\hline & 1 & 2 & 3 & 4 \\
\hline $\begin{array}{l}\text { MC4. Management presides the problems among the employees very well due to } \\
\text { differences in status within the organization. }\end{array}$ & .857 & & & \\
\hline $\begin{array}{l}\text { MC3. Management manages the coordination of activities within the organization very } \\
\text { well. }\end{array}$ & .794 & & & \\
\hline MC1. Management successfully performs process management within the organization. & .752 & & & \\
\hline $\begin{array}{l}\text { MC5. The decisions taken by the management following the competitors are quite } \\
\text { successful. }\end{array}$ & .697 & & & \\
\hline MC2. Management manages conflicts between employees very well. & .618 & & & \\
\hline PI3. Products should not be imitated. & & .903 & & \\
\hline PI2. We focus on customer orientation in new product development. & & .882 & & \\
\hline PI1. In the development of new products, attention is paid to be the first in the market. & & .852 & & \\
\hline PI4. The importance of product innovation increases the size of the market. & & .834 & & \\
\hline PI5. The importance of product innovation creates value. & & .812 & & \\
\hline BP6. The return rate of assets is quite good in the enterprise. & & & .857 & \\
\hline BP5. Overall profitability of the company is quite good. & & & .794 & \\
\hline BP3. Brand equity of the company is quite good. & & & .752 & \\
\hline BP2. Market share and growth rate of the company is quite good. & & & .725 & \\
\hline BP7. The income of the enterprise is quite good. & & & .697 & \\
\hline BP1. The market share of the business is quite good. & & & .658 & \\
\hline TO1. Information systems play an important role in decision-making. & & & & .710 \\
\hline TO4. We tend to utilize technologies to support our strategic planning. & & & & .700 \\
\hline TO2. We are actively using information systems with a focus on technology. & & & & .698 \\
\hline TO3. We conduct a comprehensive analysis. & & & & .646 \\
\hline \multicolumn{5}{|l|}{$\begin{array}{l}\text { Extraction Method: Principal Component Analysis. } \\
\text { Rotation Method: Varimax with Kaiser Normalization. }\end{array}$} \\
\hline a. Rotation converged in 5 iterations. & & & & \\
\hline
\end{tabular}

MC: Management Capability, TO: Technology orientation, PI: Product innovation, BP: Business performance

Reliability Analysis; reliability and validity of the scales should be investigated in order to give meaningful results to the scales used in the survey technique. Reliability is the consistency between independent measurements of the same thing. With the reliability analysis, it is aimed to determine the variables that do not share the common value to be measured with the scale and to increase the internal consistency of the scale by excluding these variables reliability analysis results are given in Table 2 . 
Table 2. Reliability

\begin{tabular}{|c|c|c|}
\hline Variables & Number of Questions & Cronbach Alfa (a) Values \\
\hline Management Capability & 5 & .857 \\
\hline Technology Orientation & 4 & .783 \\
\hline Product Innovation & 5 & .928 \\
\hline Business Performance & 6 & .820 \\
\hline
\end{tabular}

Correlation Analysis; The correlation test provides an examination of the structure and amount of the relationship between the variables. The aim of the correlation test is; to determine in which direction the dependent variable (Y) changes when the independent variable (X) changes (Kalayc1, 2009: 115). The strength of a relationship is indicated by the amount of the relationship between the two variables, and this value is expressed as the correlation coefficient. Correlation coefficients (r) are between -1 and +1 . If the correlation coefficient is 0 , it means that there is no relationship between the variables, the correlation coefficient is +1.00 positive linear relationships, and the correlation coefficient -1.00 means that there is a negative linear relationship. Regardless of the sign of the correlation coefficient, the value being below 0.30 indicates a low, the value being between 0.30 and 0.69 indicates a medium, and a value of 0.70 and above indicates a high level of relationship. The statistical significance of the correlation requires hypothesis testing (Çokluk et al. 2012: 52).

Table 3. Correlations

\begin{tabular}{|c|c|c|c|c|c|}
\hline \multicolumn{6}{|c|}{ Correlations } \\
\hline & & $\begin{array}{l}\text { Technology } \\
\text { orientation }\end{array}$ & $\begin{array}{l}\text { Management } \\
\text { Capability }\end{array}$ & $\begin{array}{c}\text { Product } \\
\text { Innovation }\end{array}$ & $\begin{array}{c}\text { Business } \\
\text { performance }\end{array}$ \\
\hline \multirow{3}{*}{$\begin{array}{l}\text { Technology } \\
\text { orientation }\end{array}$} & Pearson Correlation & 1 & $.596^{* *}$ & $.259^{* *}$ & $.657^{* *}$ \\
\hline & Sig. (2-tailed) & & 0.000 & 0.000 & 0.000 \\
\hline & $\mathrm{N}$ & 310 & 310 & 310 & 310 \\
\hline \multirow{3}{*}{$\begin{array}{l}\text { Management } \\
\text { Capability }\end{array}$} & Pearson Correlation & $.596^{* *}$ & 1 & $.429^{* *}$ & $.955^{* *}$ \\
\hline & Sig. (2-tailed) & 0.000 & & 0.000 & 0.000 \\
\hline & $\mathrm{N}$ & 310 & 310 & 310 & 310 \\
\hline \multirow[t]{3}{*}{ Product Innovation } & Pearson Correlation & $.259^{* *}$ & $.429^{* *}$ & 1 & $.391^{* *}$ \\
\hline & Sig. (2-tailed) & 0.000 & 0.000 & & 0.000 \\
\hline & $\mathrm{N}$ & 310 & 310 & 310 & 310 \\
\hline \multirow[t]{3}{*}{ Business performance } & Pearson Correlation & $.657^{* *}$ & $.955^{* *}$ & $.391^{* *}$ & 1 \\
\hline & Sig. (2-tailed) & 0.000 & 0.000 & 0.000 & \\
\hline & $\mathrm{N}$ & 310 & 310 & 310 & 310 \\
\hline
\end{tabular}

In quantitative research, regression analysis was performed to test hypotheses; simple regression and multiple regression. The purpose of regression analysis; It is the analysis method used to examine the relationships between variables (Küçüksille, 2010: 199). According to Kalaycı (2008), regression analysis indicated that the relationship between one dependent variable and independent variable or more than one independent variable was explained by mathematical equation (Kalayc1, 2008).

Table 4. Regression Analysis Results of Impact of Independent Variables (IV) on Dependent Variables (DV)

\begin{tabular}{|c|c|c|c|c|c|}
\hline IV & DV & Standard $\beta$ & Sig. & Adjusted R Square & F Value \\
\hline Management Capability & Technology Orientation & $.596 * * *$ & .000 & .353 & 188.362 \\
\hline Management Capability & Product Innovation & $.429 * * *$ & .000 & .181 & 76.921 \\
\hline Management Capability & Business Performance & $.955 * * *$ & .000 & .912 & 3576.169 \\
\hline Technology Orientation & Product Innovation & $.259 * * *$ & .000 & .065 & 24.668 \\
\hline Technology Orientation & Business Performance & $.657 * * *$ & .000 & .430 & 259.577 \\
\hline
\end{tabular}


Journal of Global Strategic Management | V. 14 | N. 1 | 2020-June| isma.info | 005-018 | DOI: 10.20460/JGSM.2020.282

Regression analysis is used to estimate the value of dependent variable which is difficult to obtain with the help of independent variables. To find out if the hypotheses are supported sig. value. If the values are appropriate, hypotheses are tested.

Table 5. Hypotheses

\begin{tabular}{|l|l|l|}
\hline Hypotheses & $\begin{array}{l}\text { Supported } \\
\text { Unsupported }\end{array}$ & $\begin{array}{l}\text { Significance } \\
\text { Level (Sig.) }\end{array}$ \\
\hline H1: Management capability has a positive effect on technology orientation & Supported & $\boldsymbol{P}<\mathbf{0 . 0 0 1}$ \\
\hline H2: Management capability has a positive effect on product innovation & Supported & $\boldsymbol{P}<\mathbf{0 . 0 0 1}$ \\
\hline H3: Management capability has a positive effect on business performance & Supported & $\boldsymbol{P}<\mathbf{0 . 0 0 1}$ \\
\hline H4: Technology orientation has a positive effect on product innovation & Supported & $\boldsymbol{P}<\mathbf{0 . 0 0 1}$ \\
\hline H5: Technology orientation has a positive effect on business performance & Supported & $\boldsymbol{P}<\mathbf{0 . 0 0 1}$ \\
\hline
\end{tabular}

As a result of regression analysis, it is seen in Table 5 that independent variables have an effect on dependent variables and hypotheses are supported. Regression analysis was done for the analysis of mediator variable effect and the results are shown in table 6.

Table 6. The Effect of the Mediation Variable (MV)

\begin{tabular}{|c|c|c|c|c|c|c|}
\hline & IV & DV & Standard $\beta$ & Sig. & $\begin{array}{l}\text { Adjusted } \\
\text { R Square }\end{array}$ & F Value \\
\hline \multirow{2}{*}{ Regression } & Management Capability (IV) & \multirow{2}{*}{ Product Innovation } & $.425 * * *$ & .000 & .181 & 76.921 \\
\hline & Technology Orientation (MV) & & .006 & .919 & .179 & 38.355 \\
\hline \multirow{2}{*}{ Regression } & Management Capability (IV) & \multirow{2}{*}{ Business Performance } & $.874 * * *$ & .000 & .912 & 3576.169 \\
\hline & Technology Orientation (MV) & & $.136 * * *$ & .000 & .924 & 2090.676 \\
\hline
\end{tabular}

In the analysis of the mediating variable effect, the hypothesis 6 was rejected. The reason for this was that the variable effect of the technology orientation mediation was meaningless. The hypothesis 7 was supported by analysis and the technology orientation mediation variable effect was found to be significant. We can also analyze the mediation variable effect with the Sobel test. The Sobel test includes the ratio of the product of coefficient estimates a and $b$ to the standard error of that product. Many formulas have been proposed to estimate this standard error; however, differences often have insignificant effects on test results (MacKinnon et al. 2002; Preacher and Hayes, 2004). The coefficient A denotes the path between the independent variable and the mediating variable, Sa denotes the standard error of this path (coefficient), the coefficient $b$ denotes the path between the mediating variable and the dependent variable, Sb denotes the standard error of this path. As a result of the calculation, $Z$ value of mediation effect is obtained. This value is used to assess whether the mediating effect is statistically significant using the probabilities corresponding to the standard normal distribution. 
Table 7. Sobel Test

Sobel / Aroian / Goodman Analysis; Determine whether the technology orientation mediation variable has an effect on the relationship between management capability and product innovation;

\begin{tabular}{|l|l|l|l|l|l|l|l|}
\hline Variables & & & Input: & & Test statistic: & Std. Error: & p-value: \\
\hline IV & $\begin{array}{l}\text { Management } \\
\text { Capability }\end{array}$ & $\mathrm{a}$ & 0.572 & Sobel test: & 0.10526001 & 0.05434162 & 0.91616949 \\
\hline MV & $\begin{array}{l}\text { Technology } \\
\text { Orientation }\end{array}$ & $\mathrm{b}$ & 0.010 & Aroian test: & 0.10497742 & 0.05448791 & 0.91639373 \\
\cline { 2 - 8 } & $\mathrm{Sa}$ & 0.042 & Goodman test: & 0.1055449 & 0.05419494 & 0.91594344 \\
\hline DV & $\begin{array}{l}\text { Product } \\
\text { Innovation }\end{array}$ & $\mathrm{Sb}$ & 0.095 & & & & \\
\hline
\end{tabular}

We can explain that there is an effect of the mediation variable between the variables because $\mathrm{p}$ value is less than 0.05 .

Sobel / Aroian / Goodman Analysis; Determining whether the technology orientation mediation variable has an effect on the relationship between management capability and business performance;

\begin{tabular}{|l|l|l|l|l|l|l|l|}
\hline Variables & & & Input: & & Test statistic: & Std. Error: & p-value: \\
\hline IV & $\begin{array}{l}\text { Management } \\
\text { Capability }\end{array}$ & $\mathrm{a}$ & 0.572 & Sobel test: & 6.51012978 & 0.01107075 & 0 \\
\hline MV & $\begin{array}{l}\text { Technology } \\
\text { Orientation }\end{array}$ & $\mathrm{b}$ & 0.126 & Aroian test: & 6.49663239 & 0.01109375 & 0 \\
\cline { 2 - 8 } & $\mathrm{Sa}$ & 0.042 & Goodman test: & 6.52371165 & 0.0110477 & 0 \\
\hline DV & $\begin{array}{l}\text { Business } \\
\text { Performance }\end{array}$ & $\mathrm{Sb}$ & 0.017 & & & & \\
\hline
\end{tabular}

The H7 Hypothesis is supported by testing the mediation effect made by regression analysis as a result of the Sobel test.

Hypothesis results;

Table 8. Supported / Unsupported Research Hypotheses

\begin{tabular}{|l|l|l|}
\hline Hypotheses & $\begin{array}{l}\text { Supported / } \\
\text { Unsupported }\end{array}$ & $\begin{array}{l}\text { Significance } \\
\text { Level (Sig.) }\end{array}$ \\
\hline $\begin{array}{l}\text { H6: There is a mediation variable positive effect of technology orientation on the } \\
\text { relationship between management capability and product innovation }\end{array}$ & Unsupported & \\
\hline $\begin{array}{l}\text { H7: There is a mediation variable positive effect of technology orientation on the } \\
\text { relationship between management capability and business performance }\end{array}$ & Supported & $\boldsymbol{P}<\mathbf{0 . 0 0 1}$ \\
\hline
\end{tabular}

As a result of Sobel test, hypothesis 6 was not supported and hypothesis 7 was supported. While it is expected to have an effect on mediation variable technology orientation, product innovation, it can be assumed that the management capability directly affects product innovation. We can assume that a meaningless relationship emerges when technology focus is activated, as the talent for product innovation is eliminated.

\section{CONCLUSION AND DISCUSSIONS}

The ultimate goal of an enterprise is to maintain its existence for a long time by providing sustainable success. When the dynamics of today's business world are taken into consideration, the survival of the enterprises in this challenging process depends on their capability to produce effectively and effectively, to apply the right strategic decisions in a timely manner and to differentiate itself from their competitors. As a result of the information age in which information is readily accessible, rapid technological change and rapid globalization along with the rapid spread of information and technology has led to the establishment of a more conscious consumption habit by expanding the area of customer preferences and expectations 
(Metcalfe, 2018). All these factors have made the competitive environment facing businesses more challenging. For this reason, the competencies of executives in the top management of organizations must bring success both in product innovation and business performance (Visnjic et al. 2016). Because, changing environmental conditions created an opportunity for the emergence of new technologies and a period called technological innovation process emerged with many formations, the effects of this process on the macro and micro levels starting from individuals have effects on the welfare level of the society. The rapid changes in the field of technology obliged the companies in the production sector to have a dynamic structure in terms of product innovation (Liu and Atuahene-Gima, 2018). When the results of the research are examined, the effects of independent variables on the dependent variable are supported. This means that both management capability and technology orientation have a positive impact on product innovation and operational performance. Therefore, it can be said that adaptation to technological innovations is of great importance. Otherwise, it will not be possible to exist in a competitive market. One of the results reached in the study is that managers show significant resistance to change, especially if they lack in managing change. Especially in H6 hypothesis; In the relationship between management capability and product innovation, the effect of technology orientation mediation could not be supported. This situation was not supported in the analysis results because it creates a complexity according to our assumption. However, since it will not be possible to be totally opposed to the changes in today's conditions, the resistance of the managers will continue to a certain point. One of the results reached in the study is that managers show significant resistance to change, especially if they lack in managing change. The changes that occur in the processes of the enterprises have made the performances of the enterprises quite important. In this context, the examinations conducted under the title of firm performance have shown that quantitative and qualitative performance has become more important with the rapid change in the world of technology. This result, which appears to be a return of increasing competition conditions, has prevented the quantity of the qualities of the performances performed both at the individual and organizational levels. Researchers who want to do research in this field will be able to bring new concepts into literature by focusing on technology focus by sector and their impact on both innovation and organization. 


\section{REFERENCES}

Abraham, S. (2011), Talent management strategies of an international bank in the Middle-East. In International conference on technology and business management, pp. 608-617.

Aloulou, W. J. (2019), Impacts of strategic orientations on new product development and firm performances: Insights from Saudi industrial firms. European Journal of Innovation Management, 22(2), pp. 257-280.

Atuahene-Gima, K. and Ko, A. (2001), An empirical investigation of the effect of market orientation and entrepreneurship orientation alignment on product innovation. Organization Science, 12(1), 54-74.

Baxter, M. (2018). Product design.CRC Press.

Behn, R. D. (2003), Why measure performance? Different purposes require different measures. Public administration review, 63(5), pp. 586-606.

Bilgen, B. (2001), Performans ölçme sistemlerinin incelenmesi. II. Ulusal Üretim Araştırmaları Sempozyumu. İstanbul: İstanbul Teknik Üniversitesi İşletme Fakültesi.

Calás, M. B. and Smircich, L. (Eds.). (2019). Postmodern management theory. Routledge.

Chiu, S. K. (2005), The linkage of job performance to goal setting, work motivation, team building, and organizational commitment in the high-tech industry in Taiwan. Nova Southeastern University.

Çokluk, Ö., Şekercioğlu, G. and Büyüköztürk, Ş. (2012), Sosyal bilimler için çok değişkenli istatistik (2. bask1). Ankara: PegemA Yayıncılık.

De Massis, A., Frattini, F., Pizzurno, E. and Cassia, L. (2015), Product innovation in family versus nonfamily firms: An exploratory analysis. Journal of Small Business Management, 53(1), pp. 1-36.

Dougherty, D. (2017), Organizing for innovation in complex innovation systems. Innovation, 19(1), pp. $11-15$.

Dunne, D. D. and Dougherty, D. (2016), Abductive reasoning: How innovators navigate in the labyrinth of complex product innovation. Organization Studies, 37(2), pp. 131-159.

Estrada, I., Faems, D. and de Faria, P. (2016), Coopetition and product innovation performance: The role of internal knowledge sharing mechanisms and formal knowledge protection mechanisms. Industrial Marketing Management, 53, pp. 56-65.

Fritsch, M. and Meschede, M. (2001), Product innovation, process innovation, and size. Review of Industrial organization, 19(3), pp. 335-350.

Fynes, B., Coughlan, P., von Haartman, R. and Bengtsson, L. (2015), The impact of global purchasing and supplier integration on product innovation. International Journal of Operations \& Production Management, 35( 9), pp. 1295-1311. https://doi.org/10.1108/IJOPM-03-2015-0128

Gatignon, H., \& Xuereb, J. M. (1997). Strategic orientation of the firm and new product performance. Journal of Marketing Research, 34(1), pp.77-90.

Grady, M.W. (1991), Performance measurement: implementing strategy. Strategic Finance, 72(12), p. 49.

Im, S., Vorhies, D. W., Kim, N. and Heiman, B. (2016), How knowledge management capabilities help leverage knowledge resources and strategic orientation for new product advantages in B-to-B hightechnology firms. Journal of Business-to-Business Marketing, 23(2), pp. 87-110.

Jajja, M. S. S., Kannan, V. R., Brah, S. A. and Hassan, S. Z. (2017), Linkages between firm innovation strategy, suppliers, product innovation, and business performance: insights from resource dependence theory. International Journal of Operations \& Production Management, 37(8), pp. 1054-1075.

Jean, R. J. B., Sinkovics, R. R. and Hiebaum, T. P. (2014), The Effects of Supplier Involvement and Knowledge Protection on Product Innovation in Customer-Supplier Relationships: A Study of Global Automotive Suppliers in China. Journal of Product Innovation Management, 31(1), pp. 98-113. 
Johne, F. A. (2018), Industrial product innovation. Routledge.

Kalaycı, S. (2008), SPSS uygulamalı çok degiskenli istatistik teknikleri. Asil Yayın Dagıtım Ltd. Sßti,(3rd. ed.). Ankara.

Kalaycı, Ş. (2009), SPSS uygulamalı çok değişkenli istatistik teknikleri, Ankara: Asil Yayın Dağıtım Ltd.

Kannan, V. R. and Tan, K. C. (2002), Supplier selection and assessment: Their impact on business performance. Journal of supply chain management, 38(3), pp. 11-21.

Küçüksille, E. (2010), Çoklu Doğrusal Regresyon Modeli içinde SPPS Uygulamalı Çok Değişkenli İstatistik Teknikleri, Ş. Kalaycı (Ed.), 5.

Lee, Y. K., Kim, S. H., Seo, M. K.and Hight, S. K. (2015), Market orientation and business performance: Evidence from franchising industry. International Journal of Hospitality Management, 44, pp. 28-37.

Li, S., Ragu-Nathan, B., Ragu-Nathan, T. S. and Rao, S. S. (2006). The impact of supply chain management practices on competitive advantage and organizational performance. Omega, 34(2), pp. 107124.

Liu, W. and Atuahene-Gima, K. (2018), Enhancing product innovation performance in a dysfunctional competitive environment: The roles of competitive strategies and market-based assets. Industrial Marketing Management, 73, pp. 7-20.

MacKinnon, D. P., Lockwood, C. M., Hoffman, J. M., West, S. G. and Sheets, V. (2002), A comparison of methods to test mediation and other intervening variable effects. Psychological methods, 7(1), p.83.

Martínez Sánchez, A. and Pérez Pérez, M. (2005), Supply chain flexibility and firm performance: a conceptual model and empirical study in the automotive industry. International Journal of Operations \& Production Management, 25(7), pp. 681-700.

Metcalfe, S. (Ed.). (2018), Evolutionary theories of economic and technological change: present status and future prospects (Vol. 44). Routledge.

Mithas, S., Ramasubbu, N. and Sambamurthy, V. (2011), How information management capability influences firm performance. MIS quarterly, 35(1), p. 237.

Neely, A. (2007), Business performance measurement: Unifying theory and integrating practice. Cambridge University Press.

Prahalad, C. K. and Hamel, G. (1990), The core competence ofthe corporation. Harvard Business Review, 3.

Prajogo, D. I. (2016), The strategic fit between innovation strategies and business environment in delivering business performance. International Journal of Production Economics, 171, pp. 241-249.

Preacher, K. J. and Hayes, A. F. (2004), SPSS and SAS procedures for estimating indirect effects in simple mediation models. Behavior research methods, instruments, \& computers, 36(4), pp. 717-731.

Rajala, R. and Westerlund, M. (2012, January), The effects of service orientation, technology orientation and open innovation on the performance of software-intensive service businesses. In 2012 45th Hawaii International Conference on System Sciences (pp. 1532-1541). IEEE.

Rothaermel, F. T. and Deeds, D. L. (2006), Alliance type, alliance experience and alliance management capability in high-technology ventures. Journal of business venturing, 21(4), pp. 429-460.

Saqib, M., Zarine, R. and Udin, Z. M. (2018), Exploring the technology orientation influence on the innovativeness-performance relationship of manufacturing SMEs. International Journal of Innovation and Learning, 24(3), pp. 277-300.

Schilke, O. and Goerzen, A. (2010), Alliance management capability: An investigation of the construct and its measurement. Journal of Management, 36, pp. 1192-1219.

Selznick, P. (2011), Leadership in administration: A sociological interpretation. Quid Pro Books. 
Simonin, B. L. (1997), The importance of collaborative know-how: An empirical test of learning organization. The Academy of Management Journal, 40, pp. 1150-1174.

Smith, P. C. and Goddard, M. (2002), Performance management and operational research: a marriage made in heaven?. Journal of the Operational Research Society, 53(3), pp. 247-255.

Thomas, J. R., Nelson, J. K. and Silverman, S. J. (2015), Research methods in physical activity.Human kinetics.

Unsal, E. and Cetindamar, D. (2015), Technology management capability: Definition and its measurement. European International Journal of Science and Technology, 4(2), pp. 181-196.

Venkatraman, N. (1989), Strategic orientation of business enterprises: The construct, dimensionality, and measurement. Management Science, 35(8), pp. 942-962.

Visnjic, I., Wiengarten, F. and Neely, A. (2016), Only the brave: Product innovation, service business model innovation, and their impact on performance. Journal of Product Innovation Management, 33(1), pp. 36-52.

Weihrich, H. and Koontz, H. (1993), Management: Global Perspectives, McGraw-Hill. New York.

Wujiabudula, A. and Zehir, C. (2016), The effect of organizational learning on firm performance through product innovation. Journal of Global Strategic Management, 10(1), pp. 79-88.

Yang, M. G. M., Hong, P. and Modi, S. B. (2011), Impact of lean manufacturing and environmental management on business performance: An empirical study of manufacturing firms. International Journal of Production Economics, 129(2), pp. 251-261.

Yavuz, M. and Zehir, C. (2014), A field research on organizational learning, crisis management capability and firm performance. International Journal of Research in Business and Social Science (2147-4478), 3(3), pp. 1-17.

Yazıcıŏglu, Y. and Erdoğan, S. (2004), SPSS applied scientific research methods. Ankara: Detay Publishing.

Zehir, C. and Hemedan, I. (2020), Mediating role of learning capability in the relationship between authentic leadership and business performance. Bussecon Review of Social Sciences (2687-2285), 2(1), pp. 01-12.

Zehir, C., Gemici, E. and Kole, M. (2017), Emotional And Learning Capability And Their Impact On Team Performance And Product Innovativeness in R\&D Teams . Journal of Business Economics and Finance, 6(2), pp. 88-96

Zhou, K. Z. and Li, C. B. (2007), How does strategic orientation matter in Chinese firms?. Asia Pacific Journal of Management, 24(4), pp. 447-466.

Zhou, K. Z., Gao, G. Y., Yang, Z. and Zhou, N. (2005), Developing strategic orientation in China: antecedents and consequences of market and innovation orientations. Journal of business research, 58(8), pp. 1049-1058. 